\title{
Motivacija glasača - moralno utemeljenje odluke i odgovornosti za njezine poljedice
}

\author{
Valentina Pirić*, Ivan Ćelić**
}

\begin{abstract}
Sažetak
U radu autori, potaknuti nedavno održanim izborima za predsjednika Republike Hrvatske iznose postavke kontekstualno povezane s područjem ponašanja potrošača promatranih ovom prilikom iz perspektive glasača. Budući da je svakog korisnika usluge ujedno moguće terminološki odrediti i kao potrošača, tako je, analogno iznesenoj tvrdnji, a u okviru područja političkog marketinga, moguće svakog dionika demokratskog procesa glasovanja, odnosno glasača, definirati kao potrošača te u konačnici donositelja krajnje odluke — izići na biralište ili ne izići, glasovati za ili pak glasovati protiv. Pitanje koje se temeljem iznesenog $u$ tom konkretnom slučaju nameće je priroda same motivacije glasača. Je li tu riječ o pozitivnoj ili negativnoj motivaciji glasača, o pozitivnoj ili negativnoj pokretačkoj sili? Jesu li glasači glasovali za ili su pak glasovali protiv? Ta je dilema, između ostalog, ujedno i posljedica mnogobrojnih tvrdnji koje je bilo moguće iščitati iz hrvatskih medija, a koje bi se mogle sažeti u zaključak da su glasači zapravo glasovali protiv, odnosno da su bili negativno motivirani te time izrazili svoje nezadovoljstvo postojećim socijalnim i ekonomskim stanjem u Republici Hrvatskoj te da nisu uzimali u obzir ponuđeni program kandidata. U radu se detaljnije opisuje kontekst motivacije kao pokretačke sile potrošača, odnosno glasača — tom prilikom u kontekstu političkog marketinga, te se navode i uspoređuju tri najpoznatije teorije potrošačke motivacije. Analizom postojećeg stanja i metodom komparacije navedenih teorija autori dolaze do zaključka o snažnijem utjecaju pozitivne motivacije na donošenje odluka glasača.

Ključne riječi: pozitivna motivacija potrošača, negativna motivacija potrošača, glasači, politički marketing
\end{abstract}

* Dr. sc. Valentina Pirić, Zagrebačka škola ekonomije i managementa. Adresa: Jordanovac 110, 10000 Zagreb, Hrvatska. E-pošta: valentina.piric1@gmail.com

* * Dr. Ivan Ćelić, Klinika za psihijatriju Vrapče. Adresa: Bolnička cesta 32, 10090 Zagreb, Hrvatska. E-pošta: icelic@hkld.hr 


\section{Uvod}

Nihil novi sub sole! Iza nas su još jedni izbori za predsjednika Republike Hrvatske. Čak i u okviru mlade hrvatske demokracije na prvi je pogled moguce zaključiti - ništa novo pod suncem! Međutim, mogli bismo se na trenutak zaustaviti pred tom činjenicom i zapitati se je li moguće išta naučiti iz prethodnog iskustva u smislu ponašanja i reakcije glasača, je li moguće bolje i kvalitetnije razumjeti ono što ih potiče na djelovanje, a radi podizanja razine kvalitete odgovornog i moralnog zauzimanja glasača kao pojedinaca za opće dobro na razini zajednice, društva i države. Moguće je makar samo na trenutak promišljati o brojnim napisima koji su se mogli iščitavati u hrvatskim tiskovinama tijekom proteklog razdoblja, a koji su ponašanje glasača na posljednjim provedenim predsjedničkim izborima odredili negativno u vezi sa svojom motivacijom. Izgledalo je kao da su glasači prvenstveno glasovali protiv, a ne za. Iz toga bi bilo moguće zaključiti kako je negativna motivacija glasača uistinu snažnija pokretačka sila od pozitivne.

Međutim, je li tomu uistinu tako? Konstrukt uključenosti za mnoge je nezaobilazan u objašnjavanju potrošačkog ponašanja. ${ }^{1}$ Prema Norrisu i Johnesu, sama politička participacija predstavlja multidimenzionalan fenomen. ${ }^{2}$ Bošnjak, Galešić i Kliček tvrde da je sudjelovanje pojedinaca u različitim oblicima političkih aktivnosti povezano s mnogobrojnim čimbenicima. ${ }^{3}$ Reagiraju li glasači pozitivnije na afirmativnu političku komunikaciju ili je situacija upravo suprotna? Promišljajmo o motivaciji glasača kao o pokretačkoj sili na temelju koje počivaju demokratski procesi jedne države. Politički i društveni sustav treba mijenjati u smjeru jamstva i osiguravanja dobra svakog pojedinca i dobra zajednice. ${ }^{4}$

\section{Ponašanje potrošača, marketinška koncepcija i politički marketing}

Moderna marketinška koncepcija, podrazumijeva zadovoljavanje očekivanja društva kao cjeline te iskreno podupiranje etičkih standarda. ${ }^{5} \mathrm{U}$ svakom vremenu postaju aktualni određeni etički problemi. ${ }^{6} \mathrm{U}$ navedenom kontekstu potrebno je razmatrati motivaciju glasača kao korisnika »ponude« koja postoji na političkoj sceni. Proučavanje ponašanja potrošača kao zasebne marketinške discipline započelo je kada su ponuđači shvatili da se potrošači ne ponašaju uvijek u skladu s pretpostavkom marketinške teorije. Marketinška filozofija orijentirana

1 J. Šoša - G. Milas, Zalupljena vrata: empirijska analiza iskazanih razloga odbijanja ankete, Društvena istraživanja, 17, 4-5 (2008), 725.

2 P. Norris - D. Jones, Virtual democracy (Editorial), The Harvard International Journal of Press/ Politics, 3 (1998), 1-4.

3 M. Bošnjak - M. Galešić - B. Kliček, Determinants of online political participation in Croatia, Društvena istraživanja, 17, 4-5 (2008), 747-769.

4 J. Jelenić, Politička kultura. Opet izbori! Prisjetimo se, Obnovljeni život, 66, 4 (2011), 474.

5 M. Martinović - V. Pirić - A. Mušura, Etička pitanja vezana uz proizvod kao dio marketinškog spleta, Obnovljeni život, 66, 4 (2011), 532.

6 K. Wojtyla, Temelji etike, Zagreb, 1998, str. 19. 
na potrošače postala je poznata pod nazivom marketinška koncepcija. ${ }^{7}$ Brojne promjene u okruženju, način suvremenog života, promjene u očekivanjima i stilu življenja potrošača, promjene u samom društvu, promjene na političkoj sceni i pojava novih tehnologija, neumitno su sa sobom donijele nove spoznaje. Najnovije područje istraživanja potrošača i njihova ponašanja je područje neuromarketinga. ${ }^{8}$ Potrošač, u smislu političkog marketinga glasač, nalazi se u središtu zanimanja političara i marketinških stručnjaka angažiranih na planiranju i provedbi političkih marketinških kampanja. Kod »političkog potrošača«, socijalan status predstavlja specifičan fenomen..$^{9}$ Grbeša smatra da su stranke u medijima prepoznale agresivne i moćne komunikacijske kanale. ${ }^{10}$ Pritom valja imati na umu nužnost etičnosti u marketinškoj komunikaciji, koja se posebno treba odnositi na djelovanje u okvirima političkog marketinga. Osim toga, kandidata, stranku i program potrebno je u kontekstu proizvoda promatrati uvijek kao nedjeljiv dio marketinškog spleta. ${ }^{11}$

Prema jednom od recentnih istraživanja u odnosu na hrvatski medijski prostor i političku scenu, vidljivo je da je kod političkih stranaka prevladavala afirmativna retorika. ${ }^{12}$ Street tako analizira suvremene trendove u političkom komuniciranju, ${ }^{13}$ Balabanić i Mustapić naglašavaju da su prilozi s izjavama u kojima su se predstavnici stranaka osvrtali na svoj rad, davali razna obećanja i sl. bili afirmativni. ${ }^{14}$ Izbori imaju temeljno značenje za razumijevanje i funkcioniranje liberalno-pluralističke demokracije. ${ }^{15}$ Svojim individualnim preferencijama birači artikuliraju neophodno povjerenje u izabrane predstavnike i političke stranke. ${ }^{16}$ Nažalost, u kontekstu aktualnih hrvatskih političkih zbivanja, društvenih i gospodarskih prilika doista je potrebno postaviti pitanje — gdje smo i kako smo? Kako na situaciju i na sveukupnost stvari gleda prosječan hrvatski glasač? Koliko ga dobro poznajemo? Poznajemo li ga uopće ili nam je on potpuna nepoznanica? Pitanje morala, pitanje etike, opće je društveno pitanje. U sferi političkog marketinga nužno je djelovanje samo, isključivo u skadu s etikom, te ljudskim, društvenim i kulturnim vrijednostima promatranima u kontekstu šireg sadržaja i opsežnijeg značenja. Jednu od polazišnih točaka predstavlja i mogućnost

7 L. G. Schiffman - L. L. Kanuk, Ponašanje potrošača, Zagreb, ${ }^{7} 2004$, str. 4-5.

8 N. Lee - A. Broderick - L. Chamberlain, What is »Neuromarketing «? A Discussion and Agenda for Future Research, International Journal of Psychophysiology, 63 (2) (2007), 199-204.

9 I. Rimac, Socijalni status i politička odluka — izbori 1992, Društvena istraživanja, 1, 2 (1992), 265.

10 M. Grbeša, Suvremene izborne kampanje i kako one utječu na demokratski proces, Politička misao, 42, 1 (2006), 56.

11 Marketinški splet ili marketinški miks uspješno je operativno djelovanje marketinških činitelja (funkcija, instrumenata) na tržištu. Dakle, to je kombinacija različitih metoda koje poduzeće koristi da bi pomoću marketinga plasiralo svoju robu. Marketinški splet najbolje možemo predstaviti kroz»4P«(engl. product, price, place, promotion). Prema: F. Rocco (ur.), Rječnik marketinga, Zagreb,1993, str. 251.

12 I. Balabanić - M. Mustapić, Medijska retorika u predizbornom razdoblju 2007: Analiza dnevnoga tiska, Društvena istraživanja, 17, 4-5 (2008), 647.

13 J. Street, Masovni mediji, politika i demokracija, Zagreb : Fakultet političkih znanosti, 2003.

14 I. Balabanić - M. Mustapić, Medijska retorika u predizbornom razdoblju 2007., 659.

15 Š. Deren-Antoljak, Izbori i izborni sustavi, Društvena istraživanja, 1, 2 (1992), 217.

16 Isto, 220. 
predviđanja budućih izbornih rezultata kao i samog postotka izlaska potrošača/ glasača na birališta odnosno njihova pristupanja postupku glasovanja. ${ }^{17}$

Politika nije i ne smije biti prostor i platforma za manipulacije, lažna obećanja i programe. Autori se ne mogu oteti dojmu da se same po sebi kao uosobljenje očekivanog političkog djelovanja potrebitog hrvatskoj zbilji i posebice (uglavnom) razočaranomu hrvatskomu glasaču, javljaju riječi Sv. Ivana od Križa, koje iz tame povijesti odjekuju svojom aktualnošću poput programa političkog djelovanja koji se zalaže za opće društveno i ljudsko dobro, daleko iznad egoističnih poriva bilo kojeg pojedinca: ${ }^{18}$

Duša treba uvijek težiti: ne onomu što je lakše, nego onomu što je teže;

\section{Motivacija potrošača — pokretačka sila političkog marketinga}

Područje proučavanja motivacije potrošača predstavlja područje zanimanja brojnih autora. Potreba postaje motiv kada ju potakne dostatna razina intenziteta, a sam motiv predstavlja dovoljno jaku potrebu koja čovjeka potiče na poduzimanje neke radnje. ${ }^{19}$

Teorija očekivanja sugerira da ponašanje većinom potiču očekivanja u postizanju željenih rezultata — pozitivni poticaji. ${ }^{20} \mathrm{U}$ psihologiji su se u zadnjih pedesetak godina brojna istraživanja bavila povezivanjem glasačke odluke s raznim psihosocijalnim obilježjima glasača. ${ }^{21}$ Novija istraživanja (Caprara i Zimbardo, 2004.; Caprara i sur., 2006.; Schwartz, 2007.) upućuju na to da su u zapadnim demokracijama vrijednosne orijentacije i temeljne osobine ličnosti pojedinca dominantna odrednica političkog ponašanja i glasačkih preferencija. ${ }^{22}$ Radi boljeg razumijevanja motivacije potrošača kao pokretačke sile političkog marketinga potrebno je izdvojiti tri teorije o motivaciji, teoriju Sigmunda Freuda, Abrahama Maslowa i Fredericka Herzberga. Freud se oslanja na nesvjesne psihološke sile koje oblikuju čovjekovo ponašanje pa i samu motivaciju te ih je samim time teško razumjeti i kontrolirati, a Maslow je razvio hijerarhiju potreba. ${ }^{23}$ Sigmund Freud

17 V. Lamza, Pokušaj validacije istraživanja predizbornog javnog mnijenja na temelju rezultata izbora, Društvena istraživanja, 1, 2 (1992), 231.

18 Sveti Ivan od Križa, Misli, Split, 2011, str. 13-14.

19 P. Kotler - K. L. Keller, Upravljanje marketingom, Zagreb, 122008, str. 184.

20 M. R. Solomon - G. Bamossy — S. Askegaard - M. K. Hogg, Ponašanje potrošača: Europska slika, Zagreb, 2015, str. 17.

21 I. Ferić, Sustav vrijednosti kao odrednica dominantnih političkih preferencija, Društvena istraživanja, 17, 4-5 (2008), 615.

22 G. V. Caprara - P. G. Zimbardo, Personalizing Politics: A Congruency Model of Political Preference, American Psychologist, 59, 7 (2004), 581-594; G. V. Caprara - S. Schwartz -C. Capanna - M. Vecchione - C. Barbaranelli, Personality and Politics : Values, Traits, and Political Choice, Political Psychology, 27, 1 (2006), 1-28; S. H. Schwartz, Basic Personal Values : A Report to the National Election Studies Board, ANES Pilot Study Report, No. nes011882, 2007. URL: http:// www.electionstudies.org/resources/papers/Pilot2006/nes011882.pdf

23 A. H. Maslow, Motivation and personality, New York, 1954, str. 80-106. 
je u svojem opusu ostavio dubok, kontroverzan utjecaj na viđenje temeljnih odrednica i motiva ljudskog ponašanja. Analizirajući skivene motive ljudskog ponašanja, bio je usmjeren na prikrivene pokretače specifičnih oblika ljudskog ponašanja, razmišljajući o samoj pozadini donošenja naših odluka, baš kao i o pokretačkim silama koje na njih utječu, a kojih nismo svjesni. ${ }^{24}$ Razvio je vlastitu ideju, govoreći o idu, egu i superegu, tvrdeći da velik dio ljudskog ponašanja proizlazi iz temeljnog sukoba između težnje osobe da zadovolji svoje fizičke potrebe i neophodnosti da funkcionira kao odgovoran pripadnik društva. ${ }^{25} \mathrm{Tu}$ valja razumjeti da je id usmjeren prema neposrednomu zadovoljenju te djeluje po načelu ugode, superego je njegova protuteža te predstavlja čovjekovu savjest i radi na tome da spriječi id u njegovoj težnji prema sebičnom zadovoljenju, a ego predstavlja sustav koji posreduje između ida i superega. Ego nalazi načine zadovoljavanja ida prihvatljive vanjskomu svijetu. ${ }^{26}$

Prvi pokušaji primjene Freudeovih ideja s ciljem razumijevanja dubljih značenja motiva potrošnje provedeni su 1950-ih godina stvaranjem motivacijskog istraživanja. Pionir tog pristupa bio je Ernest Dichter. ${ }^{27}$ Za razliku od Freudeove analize podsvjesnih motiva, Abraham Maslow ponudio je pritup motivaciji kojeg je moguće smatrati općenitim, a izvorno je stvoren s ciljem razumijevanja osobnog rasta i postizanja »vrhunskog doživljaja «. ${ }^{28}$ Maslow je u osnovi formirao hijerarhijski pristup potreba u kojem svaki pojedinac, potrošač, mora dosegnuti određenu razinu prije nastojanja da dosegne narednu razinu. Uzimajući u obzir Maslowljevu hijerarhiju ljudskih potreba, važno je istaknuti da ona pomaže samo u mjeri u kojoj nas podsjeća da potrošači mogu imati različite prioritete u pogedu svojih potreba u različitim situacijama potrošnje i u raznim stadijima svojeg života. ${ }^{29}$ Herzbergova teorija razlikuje u okviru ljudskog ponašanja i motivacije čimbenike koji kod potrošača izazivaju nezadovoljstvo te s druge strane čimbenike koji izazivaju zadovoljstvo. ${ }^{30}$ Potrebe i ciljevi su u međuovisnom odnosu: jedni bez drugih ne postoje. Međutim, pojedinci nisu toliko svjesni svojih potreba, koliko su svjesni svojih ciljeva. Motivacija po svojem usmjerenju može biti pozitivna ili negativna. Ciljevi također mogu biti pozitivni ili negativni. Pozitivan cilj je onaj prema kojemu je ponašanje usmjereno, dok je negativan cilj, pa tako i u političkom kontekstu, onaj od kojeg se ponašanje odvraća. ${ }^{31}$

24 S. Freud, Psihopatologija svakodnevnog života, Beograd, 1969; S. Freud, Uvod u psihoanalizu, Beograd, 1969; S. Freud, Tumačenje snova I-II, Beograd, 1969.

25 D. A. Statt, Understanding the Consumer : A Psychological Approach, 1997, str. 63.

26 M. R. Solomon i dr., Ponašanje potrošača, str. 188.

27 Preuzeto uz prilagođavanje iz: Jeffrey F. Durgee, Interpreting Dichter's Interpretations: An Analysis of Consumption Symbolism in the Handbook of Consumer Motivation, u: H. HartvigLarsen, D. G. Mick i Ch. Alsted (ur.), Marketing and Semiotics: Selected Papers from the Copenhagen Symposium, Kopenhagen, 1991.

28 H. A. Maslow, Motivation and Personality, New York, ${ }^{2} 1970$.

29 M. R. Solomon i dr., Ponašanje potrošača, str. 187.

30 F. Herzberg, Work and the Nature of Man, Cleveland, 1966.

31 L. G. Schiffman - L. L. Kanuk, Ponašanje potrošača, str. 68. 
Iz konteksta Herzbergova pristupa vidljiva je dualnost motivacije glasača. Psihološke su teorije usmjerene na prepoznavanje motiva zbog kojih ljudi izlaze ili ne izlaze na izbore. ${ }^{32}$ Rezultati provedenih istraživanja koja je u svojem radu o apstinenciji glasača na izborima 2004. godine provela Lamza Posavec, ${ }^{33}$ u skladu su sa stajalištima istraživača kao što su primjerice Bannon (2003.), Diplock (2001.) te Pattie i Johnston (2001.), prema kojima izborne apstinente nije opravdano promatrati kao homogenu skupinu ujednačenih osobina i razloga neodazivanja na izbore, nego ih valja gledati kao različite, specifično definirane segmente. ${ }^{34}$ Istraživanja su pokazala da su rezultati izlaznih anketa sadržavali određene pristranosti. ${ }^{35}$ Otkako je na izborima 1990. uspostavljen višestranački demokratski sustav, hrvatska je politička scena ispunjena krajnje raznorodnim političkim pogledima i usmjerenjima. ${ }^{36}$ Novija istraživanja ponašanja birača bave se vrijednosnim usmjerenjima kao prediktorskim varijablama. ${ }^{37}$ Bagić i Lamza Posavec smatraju da bi i u predizbornim i ostalim istraživanjima političkog javnoga mnijenja jedan od glavnih razloga nedostatne valjanosti istraživanja mogao biti povezan $\mathrm{s}$ nepotpunim obuhvatom potencijalnih ispitanika. ${ }^{38}$

Logično je očekivati da se birači između predsjedničkih kandidata odlučuju za onog koji se najviše približava njihovim stavovima. ${ }^{39} \mathrm{U}$ ozbiljnim izbornim studijama glavne odrednice biračkog ponašanja nisu promatrane izdvojeno. ${ }^{40}$ Ogledan je primjer takva pristupa knjiga The New American Voter iz 1996. godine, Warrena E. Millera i Merrilla J. Shanksa, ${ }^{41}$ koja naslovom parafrazira klasičnu studiju o »starom « američkom biraču, gdje su autori utvrdili da je na glasovanje u američkim predsjedničkim izborima 1980-ih i 1990-ih utjecao cijeli splet odrednica. ${ }^{42}$

32 V. Lamza Posavec, Apstinencija na izborima za Hrvatski Sabor 2003. godine : Tko i zašto nije glasovao?, Društvena istraživanja, 13, 3 (2004), 385.

33 Isto, 399.

34 D. P. Bannon, Electoral participation and non-voter segmentation, Paisley, 2003; S. K. Diplock, Non-Voters, Political Disconnection and Parlamentary Democracy, Parlamentary Affairs, 55 (2002), 715-730; C. Pattie - R. Johnston, A Low Turnout Landslide: Abstention at the British General Election of 1977, Political Studies, 49 (2001), 286-305.

35 V. Lamza Posavec - D. Bagić, Izlazne ankete: iskustva u svijetu i u Hrvatskoj, Društvena istraživanja, 17, 4-5 (2008), 671-694.

36 G. Milas, Mišljenje javnosti o hrvatskim političarima i političkim strankama kao pokazatelj dimenzionalnosti i prirode hrvatskog političkog prostora, Društvena istraživanja, 1, 2 (1992), 245246.

37 O. Knutsen, Party choice, u: J. W. van Deth - E. Scarbrough, The Impact of Values, 1995, str. 461-491.

38 D. Bagić - V. Lamza Posavec, Studij slučaja: Analiza metodologije izlaznih anketa agencije Puls, Društvena istraživanja, 17, 4-5 (2008), 695-721.

39 G. Milas - J. Burušić, Ideološki i sociodemografski profili glasača hrvatskih političkih stranaka: ususret stabilnom političkom grupiranju?, Društvena istraživanja, 13, 3 (2004), 347.

40 M. Kasapović, Personalizacija izbora: mit ili stvarnost?, Društvena istraživanja, 13, 3 (2004), 366.

41 W. E. Miller — M. J. Shanks, The New American Voter, Cambridge, 1996.

42 Isto, str. 366; G. Milas, Mišljenje građana o poželjnim karakteristikama Predsjednika Republike, u odnosu na vlastito biračko opredjeljenje, Društvena istraživanja, 1, 2 (1992), 285-286. 
Osvrnimo se na glas sv. Terezije Avilske. Ta crkvena naučiteljica u svojem djelu Duševni dvorac ističe aktualnu misao: »Nemojte misliti da je sve postignuto time što se puno plače — već zdušno prionimo poslu i krepostima. ${ }^{43}$ Ilustrirajmo ovdje motivaciju potrošača kao pokretačku silu ulomkom iz knjige $U v o d u$ kršćanstvo Josepha Ratzingera: 44 »Onaj tko danas pokuša govoriti o kršćanskoj vjeri ljudima koji nisu bliže upoznati s načinom crkvenog govora i mišljenja, vrlo će brzo osjetiti kako je takav pothvat težak i neobičan. «Imat će osjećaj kako je njegova situacija opisana u poznatoj Kierkegaardovoj priči o klaunu i selu koje je zahvatio požar, priči koju iznosi Harvey Cox u svojoj knjizi Grad bez Boga.

U njoj je riječ o nekom putujućem cirkusu u Danskoj u kojem je izbio požar. Primjetivši to, direktor odmah pošalje u obližnje selo klauna, koji je već bio spreman za predstavu, da dovede pomoć, jer je postojala opasnost da vatra, zahvati i selo. Klaun pohita u selo i zamoli stanovnike da hitno dođu u cirkus koji gori i da pomognu gasiti. No, stanovnici sela smatrali su klaunovu viku tek kao izvrstan reklamni trik. Klaunovo je zaklinjanje samo još više poticalo na smijeh, dok nije najzad vatra zahvatila i selo koje je izgorjelo zajedno s cirkusom.

Nekolicina studija pokazuje da je izravan dijalog s glasačima naveden kao jedan od glavnih motivacijskih čimbenika koji potiču političke stranke i političare na korištenje društvenih medija. ${ }^{45}$ Baš kao što političke stranke i političari kao pojedinci koriste različite vrste medija da bi utjecali na ponašanje glasača, odnosno da bi ih motivirali. ${ }^{46}$

Cilj svakoga tko ozbiljno promišlja o glasaču ne bi smio ostati na razini zadovoljenja njegovih osnovnih potreba i očekivanja. Konačni je cilj potrebno postaviti na inovativan način i ljestvicu obećanja podići visoko upravo na način raumijevanja činjenice da glasači od nas danas očekuju da nadmašimo njihova očekivanja i premašimo vlastita obećanja!

\section{Moralna odgovornost glasača kao »političkog potrošača — etičko propitivanje}

Uspostavom višestranačkog društvenog sustava i uvođenjem institucije demokratskih izbora, izborni procesi i glasačko ponašanje pojedinca postaju i u nas atraktivan predmet društvenih istraživanja. ${ }^{47} \mathrm{U}$ demokratskim sustavima,

43 T. Bielecki, Ekstaza i zdrav razum - Terezija Avilska, Zagreb, 2000, str. 55.

44 J. Ratznger, Uvod u kršćanstvo - predavanja o apostolskom vjerovanju, Zagreb, 1988, str. 15-16.

45 G. S. Enli - E. Skogerbo, Personalized campaigns in party-centered politics, Information, Communication and Society, 16 (2013), 757-774; R. Karlsen, Campaign Communication and the Internet: Party Strategy in the 2005 Norwegen campaign, Journal of Elections, Public Opinion and Parties, 19 (2009), 183-202.

46 B. Kalsens, The Social Media Paradox Explained: Comparing Political Perties' Facebook Strategy Versus Practice, Social Media + Society, Oslo, 2016., str. 1-10.

47 V. Lamza, Javno mnijenje Hrvatske: Izbori 1992; Uz temu, Društvena istraživanja, 1, 2 (1992), 213. 
predizborno je razdoblje vrijeme najintenzivnije političke »ponude « ${ }^{48}$ Najveću kritičnost prema problemima u društvu iskazuju građani koji ne znaju za koga bi glasovali. ${ }^{49} \mathrm{Uz}$ odbijanje izlaska na izbore, postoje i analize koje ukazuju da su odbijanja sudjelovanja ispitanika, čak i u istraživanjima javnog mnijenja, ${ }^{50}$ postala u Hrvatskoj jedan od najvećih metodoloških i organizacijskih problema. Navedeno ukazuje na istovjetnost postojećeg problema opće prisutne indiferentnosti prosječnog glasača za aktivnim sudjelovanjem u političkom životu. Kada je riječ o glasačkom opredjeljivanju, može se reći da je politički izbor rezultat heterogenih determinanti. ${ }^{51} \mathrm{U}$ okviru novijeg psihologijskog bavljenja moralnošću izdvajaju se dva glavna pravca: jedan propitkuje njezinu relativnu istaknutost $\mathrm{u}$ formiranju globalnih impresija (Wojciszke, 1994.), a drugi je usmjeren prema propitkivanju prirode i dimenzionalnosti moralnih sustava (Haidt, 2003.). ${ }^{52}$ Uloga moralnih emocija u polarizaciji birača provjerena je istraživanjem na reprezentativnom uzorku punoljetnog stanovništva Hrvatske, provedenom prije parlamentarnih izbora 2007. godine..$^{53}$ Neka istraživanja ukazuju na smanjenje stupnja nacionalnog ponosa, koje je uočeno kod hrvatskih glasača te djeluje na njihovu motivaciju prilikom izlaska na birališta. ${ }^{54}$

Postoje također uočeni problemi općeprisutne nezainteresiranosti za lokalne ili za globalne političke teme. Navedeni su problemi dobro prikazani u nizu recentno provedenih istraživanja (Cherry, 2012.; Dostie-Goulet, 2009.; Putnam, 1995., 2000.). ${ }^{55}$ Pritom se kao glavni čimbenik apatije glasača navodi problemtika povezana s medijskim okolišem koji utječe na ponašanje i stavove potrošača. ${ }^{56} \mathrm{U}$ kontekstu nezainteresiranosti možemo razaznati stihove Petra Gudelja iz pjesme Kojoj mrviš ime: ${ }^{57}$

48 S. Rihtar, Izbori u Hrvatskoj 1992: Razlozi opredjeljivanja birača, Društvena istraživanja, 1, 2 (1992), 275.

49 I. Rimac, Strukturiranje prolitičkih problema i modernizacija društva, Društvena istraživanja, 13, 3 (2004), 405.

50 D. Bagić, Utjecaj odbijanja ankete na valjanost telefonskih predizbornih istraživanja: slučaj parlamentarnih izbora 2003. godine, Društvena istraživanja, 13, 3 (2004), 458.

51 Isto, 283.

52 B. Wojciszke, Multiple meanings of behavior: Construing actions in terms of competence or morality, Journal of Personality and Social Psychology, 67 (1994), 222-232; J. Haidt, The moral emotions, u: R. J. Davidson - K. R. Scherer - H. H. Goldsmith (ur.), Handbook of affective sciences, 2003, str. 852-870.

53 S. Rihtar - I. Ferić, Moralne emocije i poralizacija birača, Društvena istraživanja, 17, 4-5 (2008), 631.

54 I. Ferić - J. Burušić, Stabilnost nacionalnoga ponosa: usporedba godine 1998. i 2002, Društvena istraživanja, 13, 3 (2004), 436.

55 C. Cherry, Increasing youth participation: The case for a national voter pre-registration law, University of Michigan Journal of Law Reform, 45 (2) (2012), 481-515; E. Dostie-Goulet, Social networks and the development of political interest, Journal of Youth Studies, 12 (4) (2009), 405421, doi:10.1080/13676260902866512; R. D. Putnam, Bowling alone: America's declining social capital, Journal of Democracy, 6 (1) (1995), 65-78, doi:10.1353/jod.1995.0002; R. D. Putnam, Bowling alone: Collapse and revival of American community, New York, 2000.

56 K. Krolo - I. Puzek, Upotreba internetskih i društvenih mreža i participacijske dimenzije društvenog kapitala mladih na primjeru Facebooka, Društvena istraživanja, 17, 4-5 (2008), 383-405.

57 P. Gudelj, Zmija mladoženja, Baška Voda, 2007, str. 30. 
Ta zemlja, što je mrviš među prstima, kako joj je bilo ime?

Ta zemlja kojoj mrviš ime.

Nije li u njima sažeta sva dubina, iskonska težina, pa samim time i »svetost « naše odgovornosti? Odakle tada proizlazi naše »pravo« za nesudjelovanjem u političkom životu? Jesmo li posustali negdje na putu, pritisnuti nevoljama i problemima svakodnevice koja ne pita za mjesto, za vrijeme i za naše »ljudske« razloge? Erich Fromm u svojem djelu Čovjek za sebe navodi Spinozine misli koje dobro oslikavaju izrečeno: »Ako put koji ovamo vodi, i izgleda veoma težak, on se ipak može naći.«58

U sudbinskoj određenosti naroda, u predviđenoj budućnosti neka nam ne bude kao u pjesmi Njezino pismo: ${ }^{59}$

Svaki dan i svaku noć mislim na te, a ti si mene zaboravio.

Uzet ću te pod ruku i povesti tamo gdje vječno šume šume.

Gdje vječno romori more.

Voli te i danonoćno misli na te

Tvoja Smrt.

Biti glasač u Hrvatskoj danas nije laka ni jednostavna pozicija i poziva na ozbiljnu odgovornost. Valja u sebi probuditi ponešto »obamrle« motive, oživiti ih u okruženju opće društvene letargije, stagnacije i malodušnosti te se pokrenuti na djelovanje i na aktivno sudjelovanje u odlučujućim procesima političkog života države i društva. Međutim, relativno visoka razina izlaznosti glasača na birališta budi nadu u opstojnost demokracije na ovim prostorima kao i u podizanje razine svijesti hrvatskih glasača da su upravo oni ti koji su pozvani aktivno sudjelovati u demokratskim procesima te da imaju stvarno realnu mogućnost mijenjanja postojećeg stanja ako ga smatraju nezadovoljavajućim. Smatramo nužnim odbacivanje negativističke filozofije podržavanja opće društvene letargije i apatije koje se tijekom proteklih razdoblja odražavalo i kroz niske stope izlaznosti na birališta. Raspoloženje potrošača utjecat cee na odluke. ${ }^{60}$ Sustavnim identificiranjem važnih situacija uporabe moguće je stvoriti strategije segmentacije tržišta s ciljem pozicioniranja proizvoda koji će zadovoljiti konkretne potrebe. ${ }^{61}$

Ljudsku narav moguće je smatrati izvorom normi. Iz tog razaznavanja izrasta dužnost. Moralna dužnost je povezana s voljom, u odnosu je s njom, jednostavno, ona je njezinom dužnošću. Iz dužnosti volja postaje na neki način predstavnik osnovnog interesa čovječanstva, njegova moralnog biti ili ne biti. Upravo radi toga, dužnost je povezana s određenim naporom, s napetošću. Crta napetosti vodi od onoga tko jesam i onoga tko bih trebao biti. Volja je vladarica te osnovne

58 B. Spinoza, u: E. Fromm, Čovjek za sebe, Zagreb, 1986. (prije Predgovora).

59 P. Gudelj, Zmija mladoženja, str. 258.

60 K. G. Celuch - L. Showers, It's Time To Stress Stress: the Stress-Purchase/Consumption Relationship, u: Holman i Solomon (ur.), Advances in Consumer Research 18, str. 284-289; L. R. Lepisto - K. Stuenkel - L. K. Anglin, Stress: An Ingnored Situational Influence, u Holman i Solomon (ur.), Advances in Consumer Research 18, str. 296-302.

61 M. R. Solomon i dr., Ponašanje potrošača, str. 62. 
napetosti. Sv. Pavao je priznao ispravnost Ovidijeve rečenice video meliora proboque deteriora tamen sequor. Zajedno sa sv. Pavlom priznat ce tu ispravnost svaki kritičan čovjek, a pogotovo svaki kršćanin, i to ne samo propter auctoritatem, nego iz vlastitog iskustva. Pokazuje se da se ta napetost u volji nekako podvaja, odnosno jedno se drugomu suprotstavlja: nasuprot napetosti između onoga tko jesam i onoga tko nisam, ili čak ne mogu biti. ${ }^{62}$ Slijedeći trag velikog pape Ivana Pavla II., smatramo potrebnim istaknuti da $» u$ svakom vremenu postaju aktualni određeni etički problemi - danas je problem postala sama etika, o njoj samoj se naveliko i neprestano piše i govori«.63 U kakve se zapravo rasprave i dileme zaplićemo? U kojoj smo uopće mjeri dovoljno savjestan potrošač na političkoj sceni?

Nedostaje svijest da zajednica nije ništa gotovo, nego da smo zajednica mi i da je ona onakva kako je živimo. ${ }^{64}$ Mudrost se odražava u odricanju, umjerenosti, samoodricanju, dobročinstvima, čistoći, žrtvama i molitvama. ${ }^{65}$ Smisao leži upravo u činjenici da svatko od nas kao glasač ima mogućnost odabira. Uz mogućnost odabira svakako dolazi i odgovornost. Nemamo pravo za svoje nesudjelovanje u političkom odlučivanju na drugoga prebacivati odgovornost. Zašto je onda ne bismo s punim pravom koristili upravo na način kako to kao klasični potrošači činimo u našim svakodnevnim životima odlučujući o bilo kojoj razini naše kupovine, rutinski, limitirano ili ekstenzivno. Politički kontekst donošenja odluke autori smatraju ekstenzivnim, jer je »ulog « visok. A kako se čovjek može zauzeti za svoju sudbinu? Ponajprije vjerom po kojoj se ta budućnost uprisutnjuje. ${ }^{66}$

\section{Umjesto zaključka: novo doba političkog marketinga}

Vrijeme je da konačno damo prednost kulturi života, kulturi nade, tako nužno i tako bolno potrebne Hrvatskoj danas. Vrijeme je da iskreno i bez ikakve zadrške damo prednost kulturi pravedne i opravdane vjere u bolje, pravičnije, iskrenije i poštenije sutra. U kvalitetnije i ljudskije sutra. Vrijeme je da prebrodimo egzistencijalni vakuum u kojem smo se našli i kao pojedinci i kao društvo u cjelini - stanje opće dosade i nezainteresiranosti za svijet oko sebe i događanja u njemu kao i za sudbinu svojeg bližnjeg. Čovjekova je karakteristika da može živjeti samo gledajući u budućnost - sub speciae aeternitatis. I to ga spašava u najtežim trenutcima njegova života, iako se kadkad mora usredotočiti na zadatak. ${ }^{67}$ Oslonimo se dakle ovaj puta na zaključak da je hrvatski glasač konačno dao glas — za, a ne glas protiv. Dajmo prednost pozitivnoj motivaciji i afirmativnoj marketinškoj komunikaciji. Pozicionirajmo se tržišno i usmjerimo takav vid komunikacije na upravo takvu afirmativnu segmentaciju za koju smo, a potkrije-

62 K. Wojtyla, Temelji etike, str. 43-44.

63 Isto, str. 19-22.

64 Agape, Biblioteka Niz 25 - uvođenje odraslih u vjeru, Novi Sad - Zagreb, 19 - Odgovornost i sudjelovanje.

65 C. Tomić, Poruka spasenja - Svetog pisma Starog zavjeta, Zagreb, 1983, str. 300-301.

66 G. Danesi, Hod Božji i Bog hoda, Zagreb, 1984, str. 76.

67 V. Frankl, Čovjekovo traganje za smislom, Zagreb, 2010. 
pljeno analizom teorija motivacije te reakcijom i odazivom glasača na nedavno održanim predsjedničkim izborima u Republici Hrvatskoj bili svjedocima da je djelovala na konačno »probuđenog« hrvatskog glasača. Nadahnimo se stihovima fra Isidora Grabovca u pjesmi Jači, promišljajući o činjenici i o mogućnosti što možemo napraviti kao zajednica glasača, potrošača na političkom tržištu, a što kao pojedinci, svojim stavovima i pristupima navedenoj problematici: ${ }^{68}$

I zato, dok smo još ovdje, ispružimo jedni drugima ruku.

Sada je vrijeme: priznajmo i drugih muku.

Zajedno zaplovimo - upoznajmo i drugih luku.

Ne gledajmo na mogućnost aktivnog sudjelovanja u političkom životu države iz perspektive mogućnosti i slobode da biramo i da time budemo živim dionikom u konačnim rezultatima naših izbora kao na žrtvu. Biti potrošač, u temelju svojeg stanja ne ukazuje na stanje žrtve. Biti potrošač u smislu potrošača na političkom tržištu ukazuje na mogućnost uživanja u slobodi odabira, na moralnu i etičku, nazovimo to tako — radost, izbjegavajući na taj način prizvuk bilo kakvog oblika prisile, moranja, tereta ili žrtve. Stoga svaki govor o odricanju i žrtvovanju za bilo koga ili bilo koji cilj nailazi na snažan otpor, odmahivanje rukom i okretanje glavom. ${ }^{69}$ Odgovornost političara i marketinških praktičara pritom bi se mogla pojednostavljeno sažeti u topao, ljudski oblik komunikacije i motivacije potrošača, prvenstveno na afirmativan, pozitivan način. Pretvorimo »dužnost « u radost sudjelovanja.

Dijalog u kojem kršćani imaju sudjelovati snagom svojega poslanja omogućit će im da naviještaju i svjedoče svoja etička uporišta i u pluralističkom društvu pripomažu uspostavljanju etičkog konsenzusa. Stari je apologet rekao da su kršćani duša svijeta. Nema sumnje, to ima veliku važnost i za sada konkretnu politiku u kojoj su, napokon, i kršćani aktivni. ${ }^{70}$ Pred nama se, otvara sada prostor slobode. Postavlja se pitanje kako u tom prostoru slobode živjeti svoju kršćansku egzistenciju, kako to što se sada pojavljuje kao izazov ugraditi u svoj kršćanski identitet? ${ }^{71}$ Rajmund Kupareo u svojim Ogledima iz estetike - umjetnik i zagonetka života jasno odgovara na to pitanje, pa zaključimo s tim: »Iako se moj nazor na svijet i život ne slaže s onim Miroslava Krleže, ipak kao sljedbenik filozofije Tome Akvinskoga moram reći da se u jednome slažemo: u traženju istine. «72 »Treba ljubiti« — kaže Toma — »i one s kojima se u mišljenju slažemo i one kojih mišljenje odbacujemo. «73 Nalazimo se na prijelomu, baš kao i u pjesmi Bone Zvonimira Šagija znakovitoga naslova Noćni zapis. ${ }^{74}$

68 I. Grabovac, Titraji dubina, Imotski, 2003, str. 30.

69 A. Grbeš, Urezan u Božji dlan - Koji smisao ima žrtva?, Zagreb, 1997, str. 120.

70 Z. B. Šagi, Izazovi otvorenih vrata — kršćansko promišljanje trenutka, Zagreb, 1993, str. 69.

71 Isto, str. 41.

72 R. Kupareo, Ogledi iz estetike - Umjetnik i zagonetka života, Zagreb, 1982, str. 162.

73 S. Thomas: Com. in Metaphys, lib. XII, lect. 9; ed Cathala, nr. 2566.26; Z. B. Šagi, Izazovi otvorenih vrata, str. 41.

74 Isto, Uvodnik. 
Kako da ohrabrim

klice

plašljivice

što bubre u mraku

minulih stradanja?

Ničite, rastite, cvatite -

Sanjam

Lisnato stablo!

T. J. Šagi Bunić govori: »Drugim riječima — narod i domovina jesu stvar i vjernika i nevjernika. Zajednička je briga i zajednička dužnost. " 75

Voter Motivation — Morally-Based Decisions and Responsibility for Consequences

Valentina Pirić*, Ivan Ćelić**

\section{Summary}

Prompted by the recent Croatian presidential elections, the authors have put forward propositions contextually related to the field of observed consumer behaviour from the voter's perspective. Since each end-user can also be termed a consumer, analogous to this claim and as seen within the framework of political marketing, each stakeholder in the democratic election process - that is, the voter - can be defined as a consumer and ultimately a final decision-maker: Should I go to the polls or not? Should I vote »for« or »against«? In this particular case, based on facts presented, the question arises as to the motivation of the voter: Is the voter positively or negatively motivated, or are we dealing with a positive or negative driving force? Have the voters voted »for or »against ? Such a dilemma is a consequence, aside from other factors, of the many claims promoted by the Croatian media which can be summed up by saying that voters had in fact voted „against«. In other words, they were negatively motivated and thus expressed their dissatisfaction with the (former) current social and economic situation in the Republic of Croatia; furthermore, they did not take into account the programs put forward by presidential candidates. This paper describes in detail the context of motivation as the consumer's, or rather the voter's driving force - this time in the context of political marketing. The three most well-known theories of consumer motivation are also cited and comparisons are drawn. Through an analysis of the current situation and comparisons among the said theories, the authors have come to the conclusion that the impact of positive motivation upon the ultimate decision of the voter has prevailed.

Key words: positive consumer motivation, negative consumer motivation, voters, political marketing

75 T. J. Šagi Bunić, Katolička crkva i hrvatski narod, Zagreb, 1983, str. 102.

* Valentina Pirić, Ph.D., Zagreb School of Economics and Management. Address: Jordanovac 110, 10000 Zagreb, Croatia. E-mail: valentina.piric1@gmail.com

** Ivan Ćelić, M.D., Vrapče Psychiatry Clinic. Address: Bolnička cesta 32, 10090 Zagreb, Croatia. E-mail: icelic@hkld.hr 